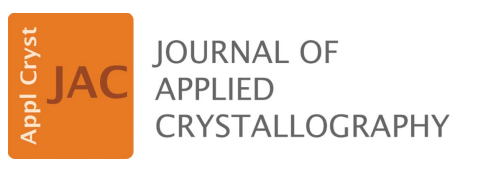

ISSN 1600-5767

Keywords: obituary.

\section{Dr H. Judith Milledge (née Grenville-Wells) (1927-2021)}

\author{
Ian Wood, ${ }^{a}$ Monica Mendelssohn ${ }^{a}$ and Mike Glazer ${ }^{b *}$ \\ a University College London, London, United Kingdom, and b University of Oxford, Oxford, United Kingdom. \\ *Correspondence e-mail: mike.glazer@jesus.ox.ac.uk
}

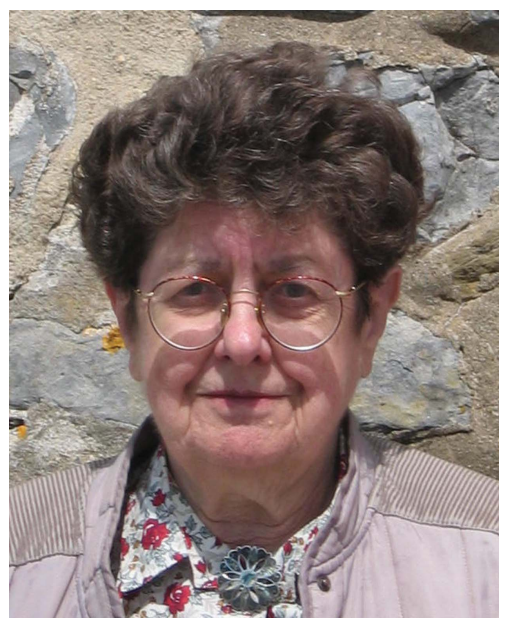

Older members of the crystallographic and mineralogical communities will remember Dr $\mathrm{H}$. Judith Milledge (née Grenville-Wells), who died in London on 23 January 2021 aged 94.

Her parents having moved from England in 1923, Judith was born in 1927 in Kokstad, South Africa (a farming community in KwaZulu-Natal, about 300 miles from Kimberley, where diamonds are famously mined), and she attended Rhodes University in the Eastern Cape Province just after the end of World War II. Judith's mother was determined that she should study a science, despite the fact that she had been to a school with no science in the curriculum. Judith said that she took physics at Rhodes because, when she was discussing the merits of taking either physics or chemistry, the professor of chemistry (probably unwilling to take on a total beginner) was very quick off the mark in assuring her that physics would be the best for her! It must have been a strange experience, as in those days very few women were admitted to university to study science. Also, the majority of Judith's fellow students were men who had just returned from active war service and who found great amusement in livening up dull classes by discovering ever more spectacular ways of destroying parts of the teaching laboratory. After taking a BSc and an MSc from Rhodes, Judith went straight to work in the new De Beers Diamond Research Laboratory in Johannesburg, but she soon realized that she needed to take a PhD in crystallography. Initially, she approached R. W. James, Chair of Physics at the University of Cape Town, but he was too unwell to take her as a student and so he suggested that she contact Kathleen Lonsdale in London instead.

In 1949, Judith left South Africa and moved to London to begin her PhD, working on diamonds at University College with Kathleen Lonsdale, and for some time she lodged with the Lonsdales in return for secretarial help in the preparation of International Tables for X-ray Crystallography. After completion of her PhD, Judith moved to a postdoctoral position at MIT, working with Sidney Abrahams. On her return to UCL, she rejoined Lonsdale's research group in the Department of Chemistry, eventually achieving the position of Reader in Crystallography in the University of London, by which time the University had also awarded her a DSc. Kathleen was one of the most important influences on Judith's life and they became close collaborators. In later years, Judith was very proud of her association with Kathleen, whom she clearly held in the highest regard, and she took her role as the executor of Kathleen's literary estate extremely seriously. By the late 1970s, after Kathleen's retirement, the Chemistry Department was going through a protracted phase of transferring to a new building, which did not suit Judith. As her readership was tenable in any department of the university, she moved to UCL's Department of Geology (now Earth Sciences), which enabled her laboratory to remain in the same location and where she spent the rest of her career. This proved to be a wise decision, both for Judith and for the Geology Department, as it laid the foundation for the excellence in mineral physics at UCL that continues to this day. Judith continued to work until well after the normal age of retirement; she was still active scientifically until well into her eighties, and co-authored her last paper aged 87. 
Judith published well over 100 scientific papers, covering an extremely wide range of topics in crystallography and mineralogy. This tendency to cast her net wide probably resulted in her being somewhat less well known than if she had focused her work more narrowly. Also, although a very intelligent and clever person, she suffered from the problem that once she had an answer to a scientific question she always felt that further work needed to be done before it was ready for publication. On one occasion, relatively recently, an editor of Nature was heard to remark to Judith along the lines that 'your work on these diamonds looks very interesting, I'm pretty sure that we would like to publish it', only to be told that 'well maybe - but I don't think it's quite finished enough to send to you yet' - a response that was greeted with incredulity by at least one younger colleague. Judith was very aware of Kathleen's frustration with her; reminiscing after her retirement, she remarked that 'Kathleen was always saying to me 'Judy, you must publish these things' - but of course I never took a blind bit of notice'.

Crystallographically, Judith had little interest in 'routine' structure determination, preferring instead to concentrate on crystals that showed disorder, phase transitions or solid-state reactions. The advent of computers in the 1950s was of great interest to crystallographers, and Kathleen Lonsdale observed to Judith that 'one of us is going to learn to use a computer and I do not think it is going to be me'. In the earlier part of her career, therefore, Judith became one of the pioneers in crystallographic computing. She was assisted in developing relevant programs, on a Ferranti Pegasus computer, by Derek Milledge from Ferranti, whom she married in 1958. Early in 1964, Kathleen and Judith acquired a Pegasus (now in the Science Museum) for their research group. Judith continued to use the Pegasus until 1980 - it had the advantage of giving her full access to what was still a relatively powerful machine (for a single user), but the disadvantage that her codes, written in a very low level language, could not easily be adopted by others. She did, though, retain an interest in the methods of structure determination, collaborating with colleagues in the Statistics Department at UCL in the use of Bayesian methods in structure refinement. Judith's interests in crystallographic techniques covered a very wide range, extending from apparatus for calculating Fourier transforms (pre electronic digital computers) to ingenious devices to improve the methods for collecting data from single crystals. During her time in the Chemistry Department, for single-crystal work, she greatly preferred to use photographic methods rather than the more fashionable approach that was then extant of using four-circle goniometers with single-point counters, arguing that one should always look at the whole of the diffraction pattern rather than just at the positions where the Bragg reflections were expected, as otherwise X-ray intensity from non-Bragg reflections, such as diffuse scattering, would be missed. She would have been very pleased to see the modern generation of instruments using area detectors.

Like Kathleen Lonsdale, Judith took the teaching of crystallography very seriously, considering that it was important to introduce students of many disciplines to crystallographic methods and also that the subject should be taught primarily by means of practical work. For the UCL Chemistry Department, they devised a week-long course during which students mounted and set a single crystal of either urea or hexamine on an oscillation camera, determined its cell parameters, measured a set of intensities, and then 'solved' the structure (assuming the phase angles were known) by producing an electron density map using a von Eller 'Photosommateur'. After she moved to the Geology Department at UCL, Judith devised a similar set of practical exercises based around mineral samples, where students learned about such things as the determination of crystal morphology, cell parameters, orientation distributions and phase identification from powder data. Sadly, the time taken, level of demonstration required and expense of running such courses means that they are probably now no longer practicable at universities in the UK; the students are much the poorer for their loss.

After joining the Geology Department at UCL, although Judith continued to collaborate with colleagues in other departments, principally in engineering, she switched the main focus of her research back to the study of diamonds, the material which, in truth, was her dominant interest throughout her career. In collaboration with Monica Mendelssohn at UCL and with colleagues in other universities, she co-authored some highly regarded papers on the formation of diamonds, their isotopic compositions, their micro and macro inclusions, and their defects. An obvious necessity for diamond research is that the researcher should have access to diamonds for which the source is accurately recorded, information which, with modern mining practices, can now often be very difficult, or impossible, to obtain. It is probably in this area that Judith's work will have its most long-lasting legacy as she had very diligently, over many years, accumulated and characterized a very large collection of well provenanced samples. After Judith retired, she arranged for her collection to be divided between South Africa and the UK, where it will provide an invaluable resource for mineralogists for many years to come.

On a personal level, Judith was essentially a rather shy person and quite reluctant to talk about herself too much. She could, though, be an excellent companion over a convivial dinner and she was a loyal friend, adviser and helper to those she enjoyed working with, especially to her former $\mathrm{PhD}$ students, several of whom have gone on to distinguished careers as scientists. One of her former students, Josh Thomas (Professor Emeritus at Uppsala University), has written of her 'She was a unique person - and it was a privilege to have had her 'pushing me' as my supervisor. However excited I was to show her some new result - she would always (not listen!) and respond: 'Now what you should REALLY do is ...'? I learnt a lot from that - to never be satisfied with my latest result. It's upset a few of my own students over the years, but it made them, like me, better (true) scientists. I have never forgotten the genius of her studying garnet and olivine inclusions in a diamond - mounted on a thermocouple. A truly inventive 'poor man's HT/HP anvil for single-crystal XRD'!!! I'll miss her - but she's always there 'in my head'!' 